\title{
O GRANDE IMAGISTA EM VELA AO CRUCIFICADO: UM ESTUDO SOBRE A LINGUAGEM DO CINEMA
}

\author{
Thais Carvalho Fonseca \\ Jorge Luiz Borges Bezerra
}

\begin{abstract}
RESUMO
A linguagem cinematográfica é reconhecida por sua capacidade de expressão e criatividade. Através da criação da câmera, na mostração, e da montagem, na narração, a narrativa do cinema se constrói. Em Vela ao Crucificado, um estudo do ponto de vista é capaz de perceber como o grande imagista mobiliza mecanismos de linguagem, presentes no curta do maranhense Frederico Machado, na construção de um discurso que se revela paradoxal.
\end{abstract}

PALAVRAS-CHAVE: grande imagista, Vela ao crucificado, discurso cinematográfico.

\section{Introdução}

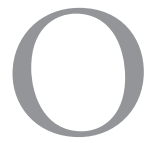

presente trabalho tem por escopo o estudo da linguagem do cinema em "Vela ao Crucificado", curta de Frederico Machado". Estudar as atuais narrativas cinematográficas se revela de grande importância

1 MACHADO, Frederico. Vela ao Crucificado. [Filme-vídeo]. Produção e direção de Frederico Machado. Brasil, Lume Produçōes cinematográficas, 2009. 1 Mídia em DVD, 13 min., color.son. Legendado, Port., ingl., franc. Frederico Machado é cineasta maranhense realizador de diversos filmes premiados tais como "Litania da velha" (1997), participante de Festivais tais como Dresden Film Festival, Cartagena Film Festival, San Diego Film Festival e Mostra Internacional de curtas de São Paulo, com inúmeros prêmios, e "Infernos" (2006), vencedor do festival de Valência na Espanha e finalista do Prêmio VIVO de Cinema Brasileiro, entre os 5 Melhores Curta Metragens do Ano no Brasil. "Vela ao Crucificado", adaptação do conto homônimo de Ubiratan Teixeira, recebeu prêmio de melhor filme, direção, ator e roteiro no Festcine amazonas 2009, e participou das seleçóes oficiais de Singapura interna- 
quando percebemos que o cinema tem se tornado a manifestação artística mais acessível às pessoas na contemporaneidade e que é, desde seu surgimento, uma arte de massa. Conforme Sabadin ${ }^{2}$, o cinema começa a se desenvolver, enquanto produção artística, apenas quando grandes empreendedores começaram a se interessar pelo potencial lucrativo dessa nova arte. Assim ocorreu com Pathé, na França, e com o surgimento dos grandes estúdios nos Estados Unidos. Martin ${ }^{3}$ acredita, contudo, que o caráter industrial do cinema constituiu uma grave desvantagem ao seu potencial artístico, "porque a importância dos investimentos financeiros que necessita o faz tributário dos poderosos, cuja única norma de ação é a da rentabilidade" ${ }^{4}$.

A questão da rentabilidade e coletividade, porém, não impediu que o cinema fosse além da técnica e se desenvolvesse como uma linguagem autônoma e artística, possuindo características próprias para tecer uma narrativa ficcional. O cinema, por isso mesmo, se constrói numa relação diferenciada com seu espectador. Tal relação ocorre numa busca do cinema por seu espectador, pois "(...) o filme ou a televisão mostram-nos as coisas já prontas" . Não que o filme não contenha o não-dito, mote da interpretação, mas “(...) o espectador cinematográfico que não pensa, no final do espetáculo estará convencido de estar levando para a casa alguma coisa (...)" ${ }^{6}$. Assim, o cinema é uma arte capaz de atingir espectadores que pensam e os que supostamente não pensam sobre o que assistem, fazendo do cinema, nos dizeres de Umberto $\mathrm{Eco}^{7}$, uma arte singularmente classista, capaz de alcançar amplos públicos e que, por isso mesmo, tira proveitos financeiros dessa potencialidade.

Dessa forma, compreender a linguagem do cinema e conhecer seu funcionamento significa perceber as maneiras diferenciadas do cinema em pro-

tional film, festival 2010, Festival Internacional de Cinema de Cartagena - Colombia 2010, Mostra Internacional de São Paulo 2009, Festcine Pantanal 2010, Iguacine 2010, Guarnicê de cine e video 2010 e Festival internacional de cinema de Atibaia 2010.

2 SABADIN, Celso. Vocês ainda não ouviram nada: a barulhenta história do cinema mudo. São Paulo: Lemos Editorial, 2000. p. 69-124.

3 MARTIN, Marcel. A Linguagem Cinematográfica. São Paulo: Brasiliense, 2003. p. 15.

4 Ibid.

5 ECO, Umberto. A diferença entre livro e filme. Entre livros, ano I, no 7, p. 98, nov. 2005. p. 98

6 Ibid.

7 Ibid. 
duzir significados e, portanto, em produzir um discurso cinematográfico. Em "Vela ao Crucificado", curta de Frederico Machado, percebe-se um uso peculiar da linguagem do cinema para construir um discurso que se mostra complexo ao reunir diferentes posturas: ao mesmo tempo que traz o tom de crítica e denúncia social através do relato do pobre enterro de uma criança, discurso este mais explícito e que atinge diretamente ao espectador, há também um discurso velado sobre a esperança, sobre a possibilidade de mudança e reversibilidade dos destinos, que só se revela através de um estudo sistemático da linguagem cinematográfica ou por um olhar crítico do espectador atento. Através de imagens, sons e palavras, o cineasta Frederico Machado constrói seu curta para falar do homem, suas dificuldades em viver e suas possibilidades em contornar um destino inexorável.

Um estudo semiótico através do instrumental da narratologia do cinema permitirá uma análise sobre os mecanismos de linguagem utilizados nesta obra cinematográfica a fim de compreender como a significação é produzida em linguagem de cinema. A partir do conceito de grande imagista, conforme discutido em Gaudreualt e Jost ${ }^{8}$ como o responsável por toda mobilização da linguagem cinematográfica na construção da narrativa, essa dualidade discursiva em "Vela ao Crucificado" será por nós avaliada. Essa instância narrativa centraliza em torno de si o ponto de vista da narrativa cinematográfica, mas quando o faz é através da uniáo de diferentes pontos de vistas presentes na narrativa cinematográfica na formação de um discurso cinematográfico capaz de apresentar uma perspectiva extremamente densa da realidade.

\section{O grande imagista no cinema: questões sobre enunciação e narração cinematográfica}

A imagem cinematográfica não pode existir independente de um ponto de vista. Segundo Cervautic ${ }^{9}$, o ponto de vista nas adaptaçóes fílmicas se refere à expressão de uma de leitura crítica da obra literária adaptada. $\mathrm{O}$ ponto de

8 GAUDREAULT, André; JOST, François. A narrativa cinematográfica. Trad. Adalberto Müller. Brasília: Ed. UnB, 2009.

9 CERVAUTIC, Andrea. El punto de vista en las adaptaciones filmicas de Don Quijote. In: https://dspace.ucalgary.ca/bitstream/1880/25422/1/47933Cervatiuc.pdf., 24/09/2011. p. 9 e 10. 
vista se constrói através da montagem cinematográfica, responsável pela diegese no cinema feita por um narrador que Gaudreault e Jost ${ }^{10}$, em seus estudos de narratologia cinematográfica, denominam de o grande imagista a partir de Laffay, ou seja, a maneira como se constrói a narrativa fílmica "desempenha um papel intelectual propriamente dito, criando ou evidenciando relaçóes entre acontecimentos, objetos e personagens"11 A partir desses autores e seus estudos sobre essa instância narrativa, passemos a uma compreensão sobre a narrativa fílmica e sua enunciação.

Segundo Laffay “o 'grande imagista' não se mostra pessoalmente: é 'um personagem fictício e invisível [...] que, nas nossas costas, folheia para nós as páginas do álbum e dirige nossa atenção apontando com um dedo discreto" ${ }^{12}$. Essa instância narrativa presente no cinema está, porém, claramente oposta a outros elementos intradiegéticos que também narram, formando uma dupla narrativa que pode ser analisada de maneira ascendente, do filme às instâncias narrativas, e descendente, das instâncias narrativas ao filme.

No primeiro caso, deve-se perceber primeiramente quais elementos nos levam à subjetividade da narrativa fílmica, isso porque um enunciado narrativo só se diferencia de um enunciado histórico pelas marcas de subjetividade que delimitam bem a presença de quem enuncia e de quem houve um enunciado. Estas marcas, indicadoras da presença de quem profere o discurso são chamadas de dêiticos, responsáveis por construir um observador-comentador ${ }^{13}$. No caso esse processo é justamente o ponto de vista no cinema cujas marcas de subjetividade podem remeter em um momento a alguém que vê a cena de dentro da diegese e, em outro momento, alguém que vê a cena fora da diegese, uma instância extradiegética, um grande imagista. A questão aqui é perceber a diferença entre um narrador explícito e a presença do grande imagista, ou seja, quando há um relato unicamente por palavras e quando há aquele que "fala" cinema por intermédio de imagens e sons; quando é possível, por exemplo, perceber algumas diferenças como: aquelas entre o que um personagem deveria ter visto e aquilo que vemos, as diferenças entre aquilo que relata o personagem e aquilo que vemos.

10 GAUDREAULT, André; JOST, François. A narrativa cinematográfica. Trad. Adalberto Müller. Brasília: Ed. UnB, 2009. p. 58

11 MARTIN, Marcel. A Linguagem Cinematográfica. São Paulo: Brasiliense, 2003. p. 152.

12 LAFFEY, 1964 apud GAUDREUALT; JOST, loc. cit.

13 KERBRAT-ORECCHONI, 1980 apud GAUDREAULT; JOST, 2009, p. 61 
No sentido descendente, é possível observar uma dupla narratividade do cinema quando o grande imagista, narrador maior, delega sua narração a narradores outros que, pela palavra, passam a narrar explicitamente. Essa dupla narratividade também está presente na literatura, porém é quase imperceptível por trabalhar apenas com a palavra, enquanto no cinema isso se torna bem marcado pelo caráter polifônico da linguagem, que permite empilhar uma série de narrativas e discursos, uma variedade de planos de enunciação e, por último, uma variedade de pontos de vistas. Estes são subnarradores, subenunciadores responsáveis pelo icônico, pelo verbal e pelo musical, que se utilizam desses diversos meios para narrar e que unidos formam o narrador fundamental, o grande imagista.

Essa situação paradoxal do cinema, que permite um jogo entre os níveis da narrativa muito mais complexo que na literatura (e que permite à narratividade dupla se manifestar plenamente), não é talvez estranha ao fato de que o narratólogo fílmico é particularmente sensível à hierarquização das instâncias. ${ }^{14}$

Nessa perspectiva, Gaudreault e Jost ${ }^{15}$ trabalham com a hipótese de que o processo de discursividade fílmica ocorre através de dois processos bem demarcados: a mostração e a narração. Na primeira há o trabalho conjunto da encenação e do enquadramento, a primeira forma de articulação cinematográfica, articulação entre fotogramas, o que corresponde ao trabalho criativo da câmera, conforme Martin ${ }^{16}$.

O segundo nível de articulação, de um nível superior ao da mostração, é a narração na qual os fotogramas procuram a ilusão de movimento contínuo e fazem nascer as unidades de segundo nível que são os planos. Aqui há uma modulaçáo temporal marcada através da atividade de encadeamento pelo processo de montagem que promove a articulação entre os planos.

Assim o grande imagista de qualquer produção cinematográfica pode ser entendido a partir de um nível superior em que “[...] a 'voz' dessas duas instân-

14 GAUDREAULT, André; JOST, François. A narrativa cinematográfica. Trad. Adalberto Müller. Brasília: Ed. UnB, 2009. p. 69.

15 Ibid, p. 74 e 75.

16 MARTIN, Marcel. A Linguagem Cinematográfica. São Paulo: Brasiliense, 2003. p. 30. 
cias seria de fato modulada e regrada por esta instância fundamental que seria, então, o 'meganarrador fílmico', responsável pela 'meganarrativa' - o filme.”17

\section{O desvelar da presença do Grande imagista em "vela ao crucificado"}

A compreensão deste grande imagista presente na narrativa cinematográfica nos permite estudar o ponto de vista, e o discurso cinematográfico que surge a partir deste, no cinema através dessas diferentes instâncias da mostração e da narração. A narrativa cinematográfica pode estar presente nestes dois níveis, numa pluralidade de pontos de vistas que narram. Em "Vela ao Crucificado", curta de Frederico Machado, podemos identificar esses diferentes pontos de vistas organizados pelo grande imagista, tendo em vista a construção de uma narrativa que mobiliza diferentes discursos.

No roteiro escrito para a elaboração do curta por Machado ${ }^{18}$ percebemos que vários pontos foram substancialmente modificados durante a produção e finalização do filme. Um dos pontos mais interessantes é a organização do flashback, não colocado no roteiro e inserido posteriormente no curta. Esse procedimento do nível da narração fornece um conhecimento por parte do narrador externo sobre todos os acontecimentos, já determinando que o grande imagista irá nos contar uma história em que o seu fim já está traçado, é destino certo e inexorável. Esse é um dos primeiros discursos inseridos por essa técnica narrativa, a impossibilidade das personagens em mudar o percurso de suas histórias.

O curta inicia com um som peculiar, é o som da mata, com ruídos de grilos e insetos sem imagem alguma, apenas um frame preto. Esse som, na sequência, passa a ser associado a um plano geral na qual um homem coloca um embrulho dentro de um buraco e após, passa a fechar este buraco, colocando terra com uma enxada. Percebe-se logo que esta primeira mostração narra sobre um cemitério e um enterro extremamente simples. A cena em que o homem, sozinho, póe uma vela em cima do monte de terra, transmite imediatamente a

17 GAUDREAULT, André; JOST, François. A narrativa cinematográfica. Trad. Adalberto Müller. Brasília: Ed. UnB, 2009. p. 75.

18 MACHADO, Frederico. Vela ao Crucificado: Roteiro para o filme curta-metragem de Frederico Machado. In: TEIXEIRA, Ubiratan. Vela ao Crucificado. São Luis: Lithograf, 2010. p. 69-82. 
ideia de que é um enterro; o homem está sozinho, sua única oferenda ao morto é uma vela. Um enterro simples, sem o elemento principal deste ritual: o caixão.

Após essa primeira sequência, passa-se para uma casa humilde em que a pobreza está claramente demonstrada não apenas pelo ambiente pobre da mesma, mas também pelas roupas das quatro personagens em cena. Uma mulher, um homem, uma criança que canta uma cantiga religiosa e tosse ao mesmo tempo, um índice sonoro de alguma doença respiratória, e uma criança morta, deitada em cima de uma mesa com as mãos cruzadas. Toda essa mostração se faz através da ocularização, auricularização e focalização.

Como explica Gaudreault e Jost, "a focalização é primeiramente definida por uma relação de saber entre o narrador e seus personagens" ${ }^{19}$, mas há ainda a questáo do ver do narrador. Tais relaçóes no ponto de vista da arte visual permitem uma divisão clara entre o ponto de vista visual e o ponto de vista cognitivo. "Segundo esse sistema, a ocularização caracteriza a relação entre o que a câmera mostra e o que o personagem deve ver" ${ }^{20}$, o ponto de vista visual, ou sonoro no caso da auricularização, e a focalização, o ponto de vista cognitivo.

No caso do cinema, o grande imagista, que se diferencia dos narradores intradiegéticos (explícitos), seja ele personagem ou comentador, manipula o conjunto da trama áudio-visual e é a partir da consciência deste por parte do espectador que se pode chegar ao discurso cinematográfico.

Da percepção da linguagem cinematográfica à idéia de enunciação, da visualização de uma narração explícita a uma narração implícita: eis duas formas de chegar ao discurso cinematográfico. Isso não quer dizer que ele possa vir a desaparecer, mas simplesmente sua presença é mais ou menos perceptível. ${ }^{21}$

No curta não há a presença de comentadores, mas apenas pequenas falas das personagens que contribuem para a narração juntamente com o conjunto de imagens selecionadas, música e sons. A narrativa cinematográfica da famí-

19 GAUDREAULT, André; JOST, François. A narrativa cinematográfica. Trad. Adalberto Müller. Brasília: Ed. UnB, 2009. p. 167.

20 Ibid. p. 168.

21 GAUDREAULT, André; JOST, François. A narrativa cinematográfica. Trad. Adalberto Müller. Brasília: Ed. UnB, 2009. p. 66. 
lia que vive o drama de enterrar um de seus membros coloca principalmente as imagens a favor da construção da teia narrativa, auxiliada por uma trilha sonora marcante e ruídos, cantos e falas significativos. Essa possibilidade polifônica de linguagem faz com que a narrativa cinematográfica se torne "apta a empilhar, uns sobre os outros, uma variedade de discursos, uma variedade de planos da enunciação e, finalmente, uma variedade de pontos de vista." 22

O velório mostrado no curta, anterior ao enterro, se passa num quadro de desolaçáo. Apenas três pessoas velam o morto. No caso o valor cognitivo da focalização espectatorial, ou seja, a focalização em que, segundo Gaudreault e $\mathrm{Jost}^{23}$, o narrador dá ao espectador esse olhar privilegiado de conhecedor de tudo o que se passa na trama, além até dos conhecimentos das personagens, permite que se saiba através dos elementos do cenário e das açóes representadas, além da ocularização zero, quando olhar da câmera não pertence a nenhum personagem, que há um velório e que esse velório é desolador. Há apenas uma vela, que está prestes a terminar e, por isso, é substituída por outra. O irmão faz o canto de morte, revelando sua própria doença com uma tosse contínua.

O homem fala para a mulher que o fim será decente, apesar de toda a pobreza mostrada e indicada pela fala do homem, e a manda espantar a barata de perto do defunto, cena esta que não é mostrada em focalização espectatorial; há um saber apenas da personagem sobre a presença da barata. No caso desta cena, há uma elipse, uma ação fora do enquadramento, como explica $\operatorname{Martin}^{24}$, e que revela uma focalização externa, que na conceituação de Gaudreault e Jost ${ }^{25}$, limita o saber do espectador em relação ao saber da personagem. Tal limitação revela o surgimento de um novo discurso, o discurso da tentativa de libertação dessas personagens da situação em que se encontram, já que o grande imagista opta, em "Vela ao Crucificado", por uma focalização predominantemente espectatorial e por uma ocularização zero. No curta, as personagens têm poucas oportunidades de narrar diretamente através de suas falas ou por uma ocularização interna, quando sabemos que a imagem da mostração é um olhar da personagem.

22 Ibid. p. 73.

23 Ibid, p. 176-182.

24 MARTIN, Marcel. A Linguagem Cinematográfica. São Paulo: Brasiliense, 2003. p. 35.

25 GAUDREAULT, André; JOST, François. A narrativa cinematográfica. Trad. Adalberto Müller. Brasília: Ed. UnB, 2009. p. 178-179. 
Todos os momentos de focalização espectatorial irão se opor, ao longo do curta, a alguns rápidos momentos, mas significativos, de uma focalização interna, o saber da personagem, ou uma focalização externa, uma limitação do saber do espectador em relação ao saber das personagens. A partir dessa primeira elipse, outras focalizaçóes diferentes da do espectador surgirão esporadicamente e contribuirão para a criação de um discurso paralelo, um discurso que quer se opor à simples crítica de uma dura realidade que não muda, que é petrificada. Passemos a destacar esses momentos significativos.

O primeiro momento será a insistência do grande imagista nos closes nos rostos da mulher e do homem. Segundo explica Martin ${ }^{26}$, o close ou primeiríssimo plano tem um significado psicológico preciso e não apenas um papel descritivo. Para este autor, o primeiro plano do rosto humano possui uma força psicológica e dramática que resgata o ser - humano, em oposiçáo ao plano geral que reduz o homem a uma silhueta minúscula, objetivando-o e dando uma tonalidade psicológica bastante pessimista. Em "Vela ao Crucificado", podemos perceber tais oposiçóes significativas através dos frames abaixo, que opóe os primeiros momentos do curta, em que o plano geral das personagens predomina, com os momentos em que surgirão vários primeiríssimos planos dos rostos das mesmas.

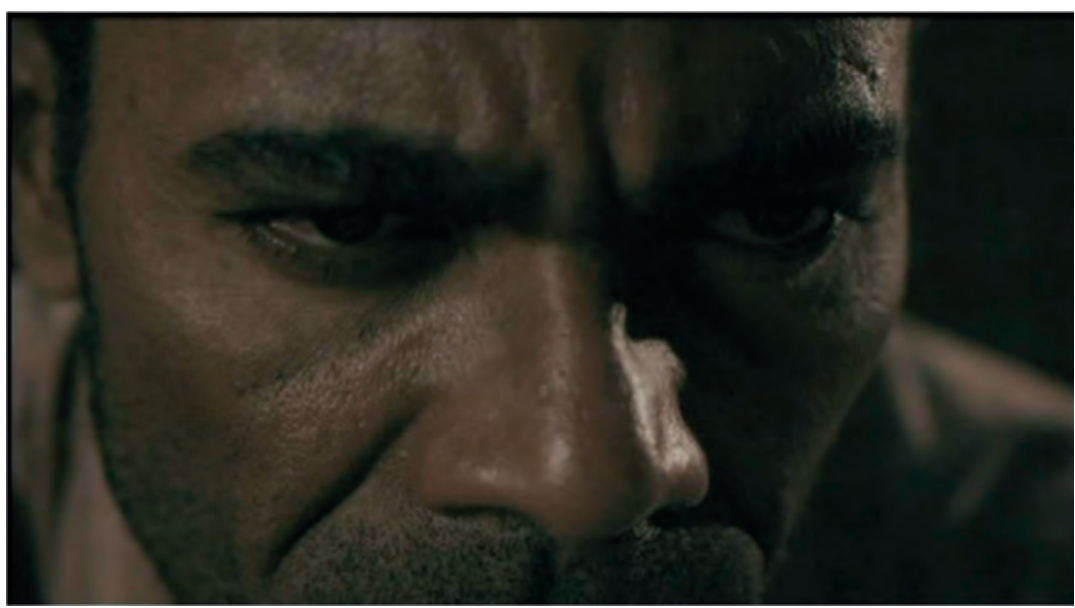

Frame 1

26 MARTIN, Marcel. A Linguagem Cinematográfica. São Paulo: Brasiliense, 2003. p. 37-39. 


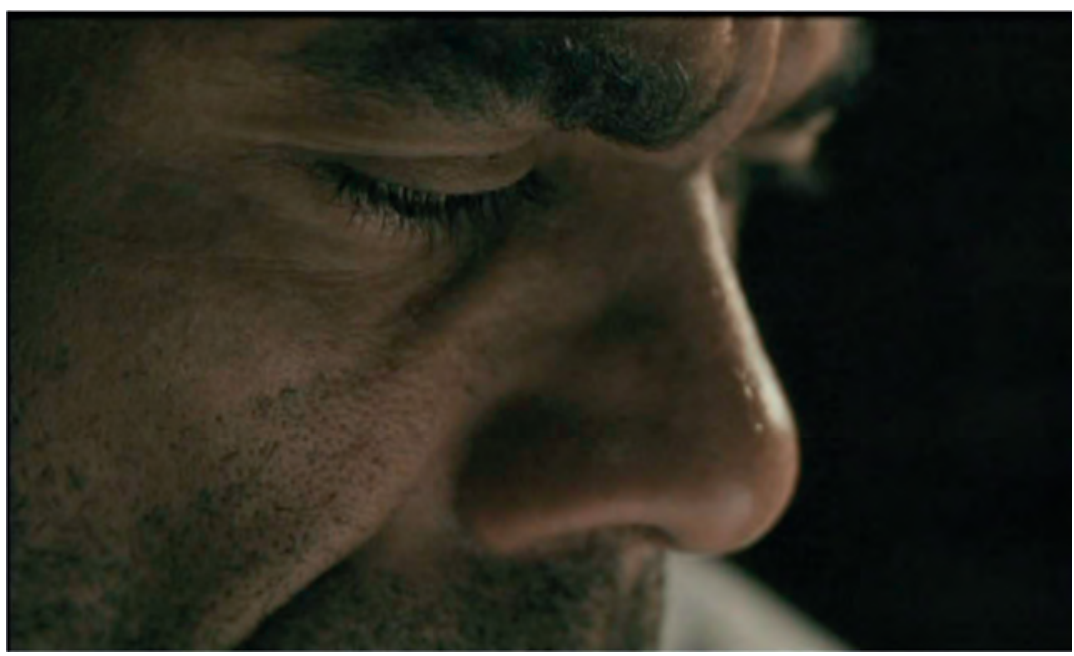

Frame 2

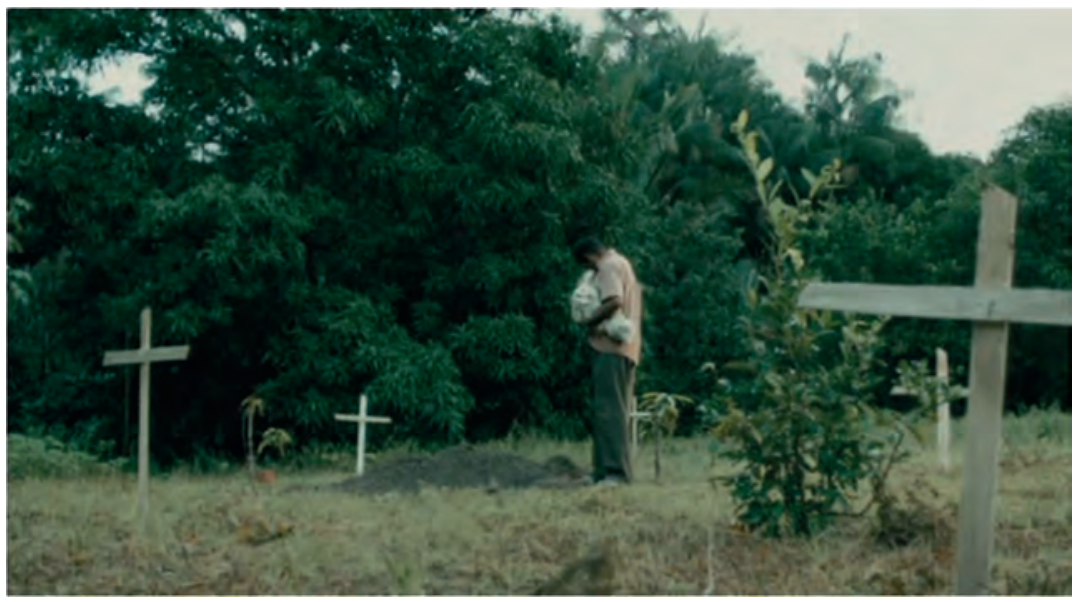

Frame 3

Estes closes, no nível da mostração, trazem um ponto de vista visual que releva essa profundidade psicológica e que introduzem o discurso da busca pelo humano. No nível da narraçáo, os closes na sequência indicam o olhar do personagem que será mostrado pela câmera, uma oportunidade de inserir a focalização interna, por cima da predominância da focalização espectatorial. Nesse momento do curta, há o registro da voz em off do homem que pensa 
sobre como o menino havia aprendido a canção que cantava. Essa auricularização mental releva um ponto de vista auricular interno. Sabe-se que esse personagem se indaga e a revelação de seu pensamento humaniza ainda mais essa personagem, inicialmente animalizada por uma associação a uma auricularização interna dos sons da mata, que iniciam o filme como única informação em fundo negro, e estão presentes na cena inicial em flashback do enterro, continuando sem interrupção na sequência do velório em casa e na caminhar do homem em direção ao cemitério para abrir a cova.

Outro momento do curta que nos leva a essa interpretação é a cena em que o homem se lava, numa mostração em planos próximos e numa narração que sugere uma sequência de preparação para enrolar o menino num pano, o substituto do caixão. Essa sequência é de focalização espectatorial, na qual a oricularização e auricularização funcionam conjuntamente na fala do homem sobre a decência do enterro, se contrapondo às imagens do homem empacotando o menino e amarrando o pacote. A lavagem em primeiro plano também carrega uma força psicológica, como nos outros closes, conforme se pode observar no frame abaixo.

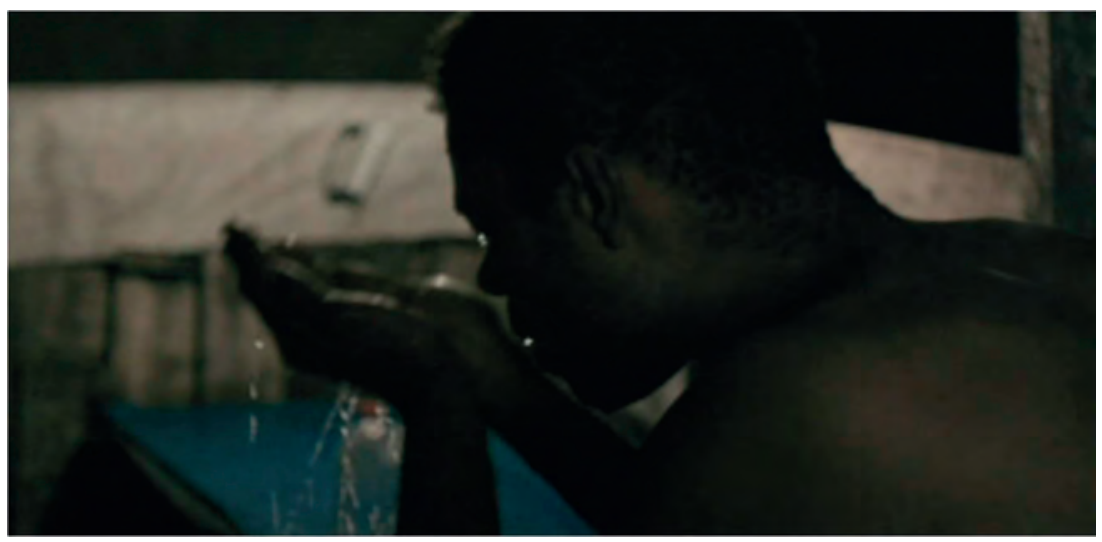

Frame 4

Essa sequência se opóe ao plano geral da preparação do defunto, momento em que o homem descarrega sua ira contra as instituiçóes sociais, que para ele apenas existem na mídia. O homem se considera abandonado pela sociedade, por isso diz não se importar com o que os outros pensam sobre as 
formas que ele irá dar ao enterro do filho. Porém, a vontade dessas personagens em mudar esse destino, que, conforme diz o homem no curta, já prometia matar o filho supostamente tuberculoso e, provavelmente também, o que estava na barriga da mulher, para aí todos também morrerem logo de vez, se revela na profundidade psicológica desses primeiros planos que humanizam as personagens, colocando-as numa possibilidade de focalização interna.

Outro momento em que também podemos perceber esse discurso é nas cenas da vela. A vela é o elemento que nomeia o curta e que se relaciona com o menino crucificado, ou seja, sacrificado pelo desprezo social. Ela está presente de maneira significativa no curta, sendo posta na narração numa focalização interna e numa focalização espectatorial, através dos mecanismos de montagem que formam a narração. Em alguns momentos, a vela é mostrada pelo grande imagista somente ao espectador, e nesse momento ela se esvai, se consome. Em contrapartida, às vezes, ela é mostrada pelos personagens que a manipulam, buscando sua conservação, sua manutenção. $\mathrm{O}$ olhar do personagem revelado pela câmera, conservando a vela, como na cena da mulher colocando uma nova vela que é revelada pela visão desta, de suas próprias mãos, realizando o ato, traz mais uma vez a focalização interna com o discurso da esperança, o discurso que traz e mantém a vela, como o único significante capaz de trazer a presença dos padróes sociais ao enterro e a possibilidade das personagens de agirem por si mesmas. Conforme se observa nos seguintes frames.

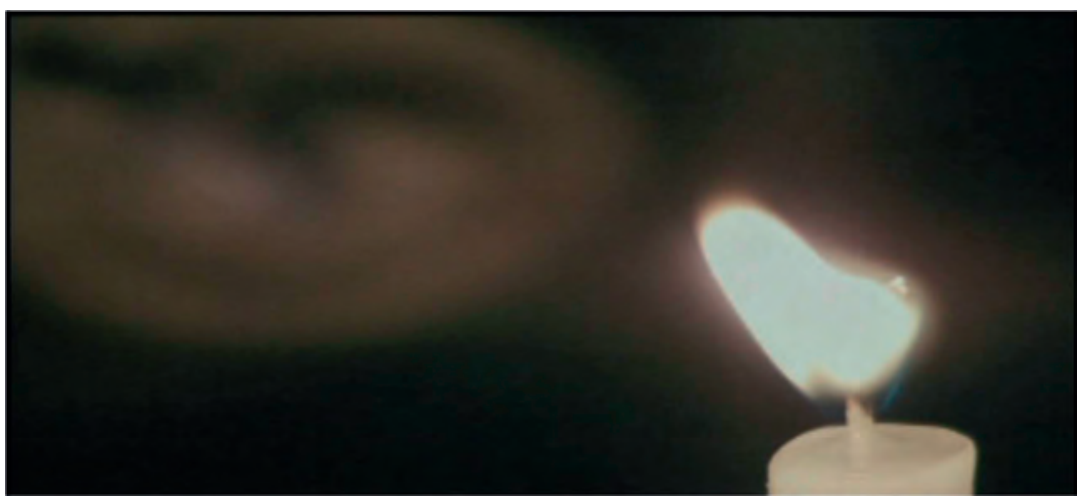

Frame 5 


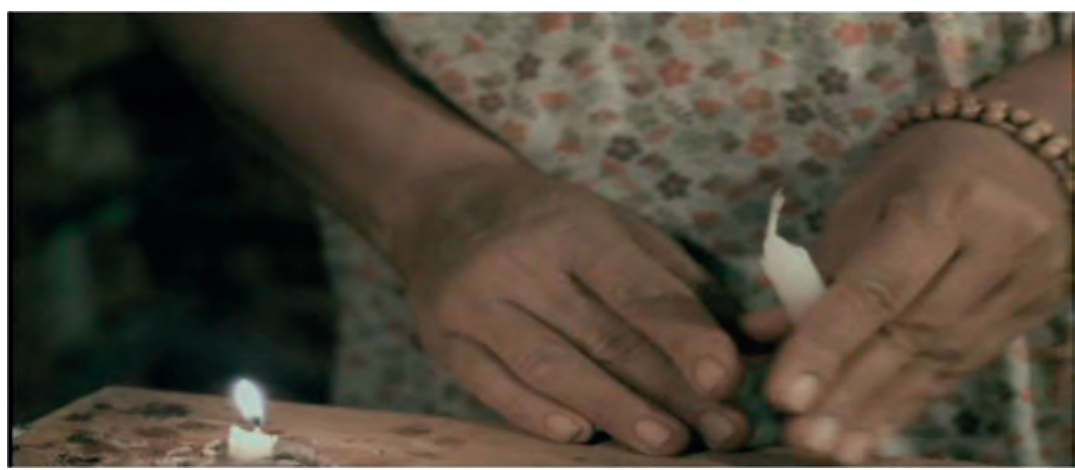

Frame 6

A última cena é decisiva para ratificar a presença desses dois discursos. A sequência final na mostração do grande imagista, numa focalização espectatorial, revela um movimento agressivo da mulher no curta. A agressividade é revelada pela focalização através da ocularização da ação da personagem e a auricularização dos sons dos golpes dados no ventre, acompanhados de uma trilha sonora produzida pelo narrador implícito, em auricularização zero. Essa trilha inicia quando há uma volta à cena inicial do curta, momento em que o enterro está sendo finalizado. O fim se cumpre afinal, mas há um retorno à casa do velório, com o primeiro plano da mulher, batendo com tanta força no ventre que pode causar no espectador um temor em atingir o bebê, como mostra o frame abaixo.

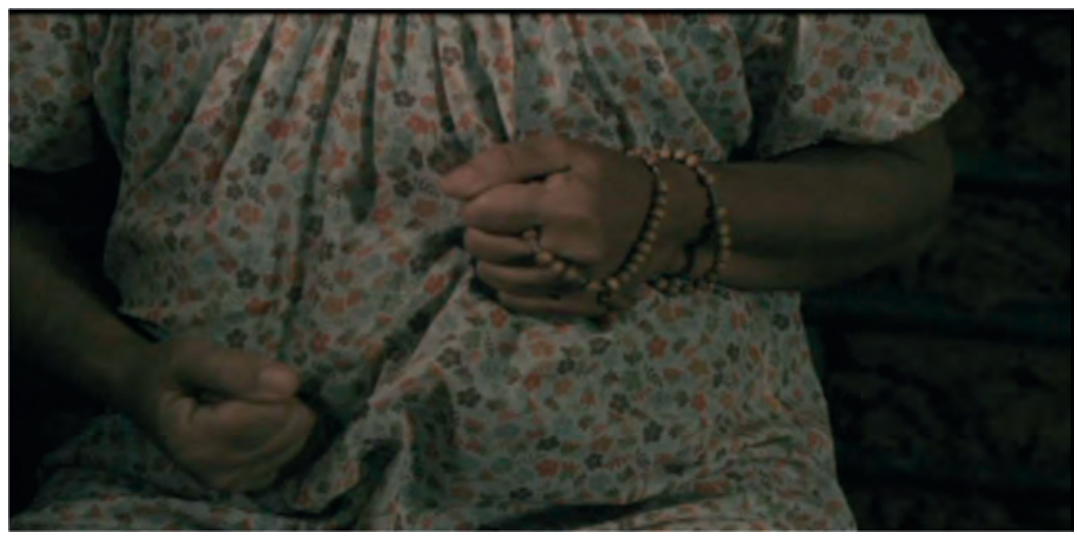


Com um travelling lateral da câmera, o saber do espectador se torna um não saber do expectador, mudando a focalização para externa. A câmera se locomove no sentido de tirar o seu olho da cena mostrada acima, passando a focalizar na sequência a parede da casa. $\mathrm{O}$ valor cognitivo dessa focalização externa nos remete ao discurso do questionamento da origem, da existência e da humanização, e até mesmo a de um assassinato. Um aborto seria a forma de aquela mulher controlar seu destino e buscar outra existência além de uma simples fêmea parideira. Tudo isso pode significar a busca por uma esperança em si mesmo na capacidade de alterar o seu próprio destino. A criação da expectativa retira o fatalismo do flashback inicial e insere por fim o elemento de esperança na trágica estória de "Vela ao Crucificado".

A criação desses discursos como se observa aqui parte do que Xavier ${ }^{27}$ destaca como a expressividade da câmera e a sua possibilidade de movimentar-se, mantendo o fluxo contínuo de imagens, além da multiplicidade de pontos de vista para focalizar os acontecimentos, algo permitido pela montagem. Percebemos, assim, que o estudo do foco narrativo em "Vela ao Crucificado" permite compreender como esses mecanismos de linguagem do cinema funcionam na busca de formar esses discursos cinematográficos que, apesar de múltiplos, estão presentes de maneira quase que difusa, necessitando de um estudo de linguagem específico que os releve e os compreenda na tessitura polifônica da narrativa do cinema.

\section{Considerações finais}

A presença de diferentes discursos que se relacionam e se opóem é uma das principais marcas do cinema. Como uma arte que reúne imagem, áudio e palavra para construir sua expressão, o cinema possui uma diversidade de mídia capaz de escoar uma diversidade de discursos. Em "Vela ao Crucificado" dois discursos que se opóem: a crítica de um destino de exclusão social inevitável, promovido pela focalização espectatorial, e a busca da humanização e esperança de mudança, na focalização interna e externa, estão presentes na trama de maneiram imbricada, formando um discurso maior promovido pelo grande imagista.

27 XAVIER, Ismail. O Discurso Cinematográfico: a opacidade e a transparência. $3^{a}$ ed. São Paulo: Paz e Terra, 2005. p. 24. 
Esse discurso maior é justamente a movimentação paradoxal de "Vela ao Crucificado" entre a inevitabilidade das condiçôes de exclusão social e uma vontade de mudar os quadros sociais impostos. Esses discursos andam conjuntamente no curta, buscando uma ideia da inevitável convivência de discursos paradoxais, já que discursos extremamente fechados são por si mesmos incapazes de dar conta da complexidade das realidades que representam. Assim, a obra de Frederico Machado revela o seu êxito na capacidade em elaborar uma narrativa cinematográfica, mostrando como o cinema possui diferentes possibilidades de trabalhar com campo da ficção, se utilizando de uma linguagem própria, a linguagem do cinema.

\section{LE GRANDE IMAGISTE EN VELA AO CRUCIFICADO: UNE ETUDE SUR LE LANGAGE DU CINEMA}

\section{RÉSUMÉ}

Le langage cinématographique est reconnue pour sa capacité d'expression et de créativité. À travers de la caméra, dans la monstration, et de la montage, dans la narration, la narrative du film est construit. Dans Vela ao Crucificado, une étude du point de vue est en mesure de voir comment le grande imagiste mobilise des mécanismes linguistiques présents dans le court-métrage de Frederico Machado, dans la construction d'un discours qui révèle un paradoxe.

MOTS-CLÉS: grande imagiste, Vela ao Crucificado, discours filmique.

Recebido em: 28/03/12

Aprovado em: 25/11/12 